\title{
Mental Health of Indonesian Female Domestic Workers in Iraqi Kurdistan Region
}

\author{
Evie Farida Sulaeman
}

Tishk International University, Erbil-Kurdistan region, Iraq

\begin{abstract}
Background and objectives: Female migrated workers face various mental difficulties. There are many Indonesian female domestic workers in the Kurdistan region. This research's main objective was to find out the level of mental health of Indonesian domestic female workers in the Kurdistan region/Iraq. More specifically, the study aimed to assess anxiety, depression, and stress levels among this population. Furthermore, the study assessed the correlation between anxiety, depression, and stress with some demographic variables.

Methods: The sample consisted of 95 Indonesian domestic female workers who are currently working in the Kurdistan region/Iraq. The study used non-random snowballing system to choose the participants. The age of the sample ranged from 20 to 54 years $(\mathrm{M}=36.11, \mathrm{SD}=$ 7.17). Face to face, as well as online interviews, were conducted with each member. Malay version of the Depression, Anxiety and Stress Scale (DASS21) was used to collect the necessary data.
\end{abstract}

Results: The study found that the mean scores of anxiety, depression, and stress among the sample were within the normal range. Way of employer treatment was significantly correlated to all three dimensions of mental health. The number of children, monthly salary, and female domestic workers' Kurdish fluency were significantly related to stress and depression, while years of stay were correlated to depression only. The family size of the employers was correlated considerably to anxiety only.

Conclusion: Although some demographic variables are essential in determining the mental health of DFWs, generally, they have good mental health.

Keywords: Mental Health, Female Domestic Workers, Indonesia, Anxiety, Depression, Stress 


\section{Proceeding of the $2^{\text {nd }}$ Scientific Conference on Women's Health 2-3 September 2020 - Hawler Medical University}

\section{INTRODUCTION}

Migrant workers are involved in a wages action in a state where they are not native. ${ }^{1}$ Migrant workers add value to their host countries' economies and their home country's means of transferring funds to boost the economy. According to The International Labour Organization (ILO) there are around 164 million migrant workers globally, and nearly 96 million are men, while 68 million are women. ${ }^{2}$ In 2018 Indonesia sent 283,640 migrant workers abroad, Of that number, 198,975 are female, and 150.000 of them are migrant domestic workers. That makes Indonesia one of the primary sources of migrant domestic workers in the world. ${ }^{3}$ Muthia and Aliya reported that sending workers, especially female migrant domestic workers abroad, has become an industry in Indonesia, and the main players in this industry include travel agents, Labour recruiters, brokers, interpreters, and housing agents. However, These workers suffer physical, psychological, and sexual abuse due to long working hours and hard working conditions. Anjara, Nellums, Bonetto, and Bortel, reported that more than half of female domestic workers, including Indonesians, who work in Singapore suffer from stress. ${ }^{4}$ Another recent study in Singapore has found that foreign domestic workers (FDW) have double the risk of developing mental health problems as compared to the general Singapore population. ${ }^{5}$ The study conducted by Humanitarian Organisation For Migration Economics (HOME) revealed that almost a quarter of the 670 FDWs ( 48.1 percent are Indonesian) surveyed are facing poor mental health. A study conducted by a Macau-based scientist shows that the number of Indonesian domestic helpers in Macau who suffer from depression stands 12 percent. ${ }^{6}$ These domestic workers are in a vulnerable position to suffer from mental illness due to their work-related exposures and current living conditions. A study found in Malaysia also shown that $14.9 \%$ of the Indonesian domestic workers have moderate and severe depression symptoms. ${ }^{1}$ In the middle east countries, a study conducted by Kamber ${ }^{7}$ found that nearly all foreign workers interviewed over a two-week period said they had been deceived by agents who arrange the journeys. Unable to communicate, some arrive not knowing what country they are in. Their employment agencies seize Their passports, and they are unable to go home. As a result of these violations, in 2015, the Indonesian Government decided to ban its maids from working in the middle east. The 21 countries affected by the ban include Saudi Arabia, Bahrain, Iraq, Iran, Kuwait, Lebanon, Egypt, Oman, Palestine, Qatar, Syria, United Arab Emirates, Yemen, and Jordan. Countries and regions not affected in the Middle East are Cyprus, Iraqi Kurdish Administration, and Turkey. ${ }^{8}$ 
Based on the data that the researcher received from the Indonesian embassy in Iraq (Aria Chandra Utama 2020, personal communication) there are 847 Indonesian people living in Iraq, 13 are The Embassy staff, 58 are university students, while the rest of 776 are Indonesians who live and work in Iraq. It is estimated that the number of female domestic workers ranges from 500 to 600.9 Although some research has been done in some countries about the mental health of Indonesian female domestic workers, such as in Malaysia, Singapore, and Macau, no such research has been conducted yet in Iraq. The main objective of this research is to find out the level of mental health of Indonesian domestic female workers in the Kurdistan region/Iraq. More specifically, the study aimed to assess anxiety, depression, and stress levels among this population. Furthermore, the study measures the correlation between anxiety, depression, and stress with some demographic variables.

\section{MATERIALS AND METHOD}

\section{Sample}

The sample of this study consists of 95 Indonesian female domestic workers who work in the Kurdistan region, Iraq. The sample was selected through the non-random snowballing method.

\section{Instrument}

The questionnaire of this research derived from the scale called Depression, Anxiety, Stress Scale 21 (DASS21) developed by Lovibond \& Lovibond (10) and has been translated into Indonesian Language, it consists of twenty-one questions with four answer options, there are: did not apply to me at all marked as 0 , applied to me to some degree or some of the time marked as 1, applied to me to a considerable degree or a good part of time marked as 2, applied to me very much or most of the time marked as 3. Depression measured by seven items $(3,5,10,13,16,17,21)$, anxiety measured by seven items $(2,4,7,9,15,19,20)$, and the last one is stress measured by seven items $(1,6,8,11,12,14,18)$.

\section{Data collection}

Some of the questionnaires were administered from personal interview through messenger, WhatsApp, and phone calls; each interview took approximately 20-30 minutes. At the same time, some of the questionnaires were administered from a direct personal interview. 


\section{Proceeding of the $2^{\text {nd }}$ Scientific Conference on Women's Health 2-3 September 2020 - Hawler Medical University}

\section{RESULTS}

This research aimed to find out the level of mental health of Indonesian female domestic workers in the Kurdistan region of Iraq. Some descriptive demographic characteristics of the sample are presented first, followed by data analysis regarding the aim of the study.

Almost half of the participants (49.5\%) were married, the majority of them (71\%) having two to three children. The educational level of the majority of the sample (56.8\%) is until the primary only. Furthermore, the monthly salary for most of them ranged from 300 to 400 US dollars, which have been staying in Kurdistan for a period of one to five years. Most of them (83\%), have been elsewhere before coming here, but they have not been back home since their arrival. The majority of them (85\%) stay in Erbil. Only a small minority (8\%) reported that their Kurdish fluency is either good or very good. A vast majority (95\%) reported that their employers treat them either in a good or very good way. The family size, whom they serve, mostly consists of five members or less. However, the majority of them (62\%) do not have a day off. Almost half of the sample (47\%) do different tasks in the employers' houses (Table 1).

Table 1: Demographic information about the sample

\begin{tabular}{lccc}
\hline variables & & Frequency & Percent \\
\hline \multirow{3}{*}{ Age } & $20-24$ & 3 & 3.2 \\
& $25-29$ & 14 & 14.7 \\
& $30-34$ & 25 & 26.3 \\
& $35-39$ & 20 & 21.1 \\
Marital Status & $40-44$ & 19 & 20 \\
& 45 and more & 14 & 14.8 \\
& Single & 2 & 2.1 \\
No. of Children & married & 47 & 49.5 \\
& Divorced & 37 & 38.9 \\
& Widowed & 9 & 9.5 \\
& 0 & 6 & 6.3 \\
& 1 & 31 & 32.6 \\
& 2 & 37 & 38.9 \\
& 3 & 12 & 12.6 \\
& 4 & 5 & 5.3 \\
& 5 and more & 4 & 4.3
\end{tabular}


Proceeding of the $2^{\text {nd }}$ Scientific Conference on Women's Health 2-3 September 2020 - Hawler Medical University

\begin{tabular}{|c|c|c|c|}
\hline \multirow[t]{3}{*}{ Education level } & Secondary lower & 25 & 26.3 \\
\hline & Secondary upper & 11 & 11.6 \\
\hline & $200-300$ & 7 & 7.4 \\
\hline \multirow{4}{*}{ Monthly salary (in US Dolars) } & $300-400$ & 58 & 61.1 \\
\hline & $400-500$ & 27 & 28.4 \\
\hline & 500 and more & 3 & 3.2 \\
\hline & Less than a year & 22 & 23.2 \\
\hline \multirow[t]{3}{*}{ Years of stay in Kurdistan } & $\begin{array}{c}\text { From one to five } \\
\text { years }\end{array}$ & 57 & 60.0 \\
\hline & $\begin{array}{c}\text { From five to ten } \\
\text { years }\end{array}$ & 13 & 13.7 \\
\hline & More than ten years & 2 & 2.1 \\
\hline \multirow{3}{*}{$\begin{array}{l}\text { First Experience working in } \\
\text { Kurdistan }\end{array}$} & Yes & 16 & 16.8 \\
\hline & No & 79 & 83.2 \\
\hline & Yes & 29 & 30.5 \\
\hline \multirow[t]{2}{*}{ Gone back home } & No & 66 & 69.5 \\
\hline & Erbil & 81 & 85.3 \\
\hline \multirow[t]{3}{*}{ City of Residence } & Suli & 2 & 2.1 \\
\hline & Duhok & 10 & 10.5 \\
\hline & Very week & 75 & 78.9 \\
\hline \multirow[t]{5}{*}{ Kurdish language proficiency } & Week & 11 & 11.6 \\
\hline & Good & 5 & 5.3 \\
\hline & Very good & 3 & 3.2 \\
\hline & Bad & 2 & 2.1 \\
\hline & Good & 59 & 62.1 \\
\hline \multirow{5}{*}{ Treatment received } & Very good & 31 & 32.6 \\
\hline & $\begin{array}{c}\text { Family size: Less than } \\
\text { five }\end{array}$ & 51 & 53.7 \\
\hline & Five & 6 & 6.3 \\
\hline & More than five & 37 & 38.9 \\
\hline & Yes & 34 & 35.8 \\
\hline \multirow[t]{2}{*}{ Having day off } & No & 59 & 62.1 \\
\hline & $\begin{array}{l}\text { Taking care of } \\
\text { elderly/sick }\end{array}$ & 10 & 10.5 \\
\hline \multirow[t]{3}{*}{ Type of work } & Taking care of children & 1 & 1.1 \\
\hline & House chores & 39 & 41.1 \\
\hline & More than one & 45 & 47.4 \\
\hline
\end{tabular}


The participant's mean scores on stress, anxiety, and depression sub-scales are 8, 5.5, and 7.8, respectively (Table 2). These mean scores are normal level. However, $10.6 \%$ of them, their stress scores were either mild or moderate. A higher percentage (31.9\%) of them; their scores on anxiety were mild and moderate, with a low percentage (4.3\%) reported severe anxiety. Those who reported mild and moderate levels of depression were $39.2 \%$.

Table 2: Mean scores, standard deviations, and percentage of stress, anxiety, and depression

\begin{tabular}{lccccc}
\hline & $\%$ & Minimum & Maximum & \multicolumn{2}{c}{ Mean Std. Deviation } \\
\hline Stress & & .00 & 19.00 & 8.05 & 4.59 \\
Normal & 89.5 & & & & \\
Mild & 7.4 & & & & \\
Moderate & 3.2 & & & & \\
Severe & 0 & & & & \\
Anxiety & & .00 & 19.00 & 5.52 & 4.24 \\
Normal & 68.4 & & & & \\
Mild & 10.6 & & & & \\
Moderate & 17.0 & & & & \\
Severe & 4.3 & & & & \\
Depression & & .00 & 17.00 & 7.83 & 4.55 \\
Normal & 61.1 & & & & \\
Mild & 25.4 & & & \\
Moderate & 13.8 & & & \\
Severe & 0 & & & \\
\hline
\end{tabular}

To find out if these three subscales are related to the participants' age, the Pearson correlation was used. The results show that age is not correlated to any one of them (Table 3).

Table 3: Correlation between age and stress, anxiety, and depression.

\begin{tabular}{|c|c|c|c|c|}
\hline \multirow{4}{*}{ Age } & & Stress & Anxiety & Depression \\
\hline & $\begin{array}{l}\text { Pearson } \\
\text { Correlation }\end{array}$ & .026 & -.045 & .008 \\
\hline & Sig. (2-tailed) & .803 & .667 & .940 \\
\hline & $\mathrm{N}=95$ & & & \\
\hline
\end{tabular}


Proceeding of the $2^{\text {nd }}$ Scientific Conference on Women's Health 2-3 September 2020 - Hawler Medical University

Using Analysis of Variance (ANOVA) one way, the result shows that marital status is not related to any of the sub-scales in this study (Table 4).

Table 4: ANOVA result of Marital status with stress, anxiety, and depression.

\begin{tabular}{llccccc}
\hline \multirow{5}{*}{ Stress } & \multicolumn{1}{c}{ Sum of } & & & & \\
& & Squares & df & Mean Square & F & Sig. \\
& Between Groups & 16.65 & 3 & 5.55 & .25 & .85 \\
& Within Groups & 1968.57 & 91 & 21.63 & & \\
\multirow{5}{*}{ Anxiety } & Total & 1985.22 & 94 & & & \\
& Between Groups & 9.79 & 3 & 3.26 & .17 & .91 \\
& Within Groups & 1686.92 & 91 & 18.53 & & \\
& Total & 1696.71 & 94 & & & \\
& Betweension Groups & 37.11 & 3 & 12.37 & .58 & .62 \\
& Within Groups & 1914.33 & 91 & 21.03 & & \\
& Total & 1951.44 & 94 & & & \\
\hline
\end{tabular}

The number of children of Indonesian female domestic workers was found to be significantly correlated to stress and depression but not with anxiety (Table 5).

Table 5: Correlation between number of children and stress, anxiety, and depression

\begin{tabular}{lllcc}
\hline \multirow{4}{*}{ children } & Pearson & $.24^{*}$ & .16 & $.21^{*}$ \\
& Correlation & & & \\
& Sig. (2-tailed) & .01 & .10 & .03 \\
& $\mathrm{~N}=95$ & & & \\
\hline
\end{tabular}

As far as monthly salary is concerned, the results show that it is correlated to stress and depression. The less the salary, the higher the level of stress and depression (Table 6). 
Proceeding of the $2^{\text {nd }}$ Scientific Conference on Women's Health 2-3 September 2020 - Hawler Medical University

Table 6: ANOVA between Salary and stress, anxiety and depression

\begin{tabular}{|c|c|c|c|c|c|c|}
\hline & & $\begin{array}{l}\text { Sum of } \\
\text { Squares }\end{array}$ & df & Mean Square & $\mathrm{F}$ & Sig. \\
\hline \multirow[t]{3}{*}{ Stress } & Between Groups & 166.05 & 3 & 55.35 & 2.76 & .04 \\
\hline & Within Groups & 1819.17 & 91 & 19.99 & & \\
\hline & Total & 1985.22 & 94 & & & \\
\hline \multirow[t]{3}{*}{ Anxiety } & Between Groups & 82.97 & 3 & 27.66 & 1.56 & .20 \\
\hline & Within Groups & 1613.73 & 91 & 17.73 & & \\
\hline & Total & 1696.71 & 94 & & & \\
\hline \multirow[t]{3}{*}{ Depression } & Between Groups & 172.82 & 3 & 57.60 & 2.94 & .03 \\
\hline & Within Groups & 1778.62 & 91 & 19.54 & & \\
\hline & Total & 1951.44 & 94 & & & \\
\hline
\end{tabular}

The education level was found not to be related to any of the sub-scales (Table 7). Nevertheless, years of stay was found to be significantly correlated to depression only (Table 8). The more they stay, the higher the level of depression.

Table 7: ANOVA between education and stress, anxiety, and depression.

\begin{tabular}{llccccc}
\hline & \multicolumn{2}{c}{$\begin{array}{c}\text { Sum of } \\
\text { Squares }\end{array}$} & df & Mean Square & F & Sig. \\
\hline $\begin{array}{l}\text { Stress } \\
\text { Groups }\end{array}$ & Between & 73.38 & 2 & 36.69 & 1.72 & .18 \\
& Within Groups & 1851.41 & 87 & 21.28 & & \\
& Tota & 1924.79 & 89 & & & \\
& 1 & & & & & \\
Anxiety & Between & 32.66 & 2 & 16.33 & .85 & .42 \\
Groups & & & & & & \\
\hline
\end{tabular}


Proceeding of the $2^{\text {nd }}$ Scientific Conference on Women's Health 2-3 September 2020 - Hawler Medical University

Table 8: ANOVA between years of stay and stress, anxiety, and depression

\begin{tabular}{|c|c|c|c|c|c|c|}
\hline & & $\begin{array}{l}\text { Sum of } \\
\text { Squares }\end{array}$ & df & Mean Square & $\mathrm{F}$ & Sig. \\
\hline \multirow[t]{3}{*}{ Stress } & Between Groups & 130.95 & 3 & 43.65 & 2.13 & .102 \\
\hline & Within Groups & 1844.83 & 90 & 20.49 & & \\
\hline & Total & 1975.78 & 93 & & & \\
\hline \multirow[t]{3}{*}{ Anxiety } & Between Groups & 25.06 & 3 & 8.35 & .45 & .716 \\
\hline & Within Groups & 1659.13 & 90 & 18.43 & & \\
\hline & Total & 1684.19 & 93 & & & \\
\hline \multirow[t]{3}{*}{ Depression } & Between Groups & 203.79 & 3 & 67.93 & 3.54 & .018 \\
\hline & Within Groups & 1723.99 & 90 & 19.15 & & \\
\hline & Total & 1927.79 & 93 & & & \\
\hline
\end{tabular}

Kurdish language proficiency was correlated to both stress and depression but not with anxiety (Table 9).

Table 9: ANOVA between Kurdish language proficiency and stress, anxiety and depression

\begin{tabular}{|c|c|c|c|c|c|c|}
\hline & & $\begin{array}{c}\text { Sum of } \\
\text { Squares }\end{array}$ & $\mathrm{df}$ & Mean Square & $\mathrm{F}$ & Sig. \\
\hline \multirow[t]{3}{*}{ Stress } & Between Groups & 203.50 & 3 & 67.83 & 3.42 & .02 \\
\hline & Within Groups & 1780.59 & 90 & 19.78 & & \\
\hline & Total & 1984.09 & 93 & & & \\
\hline Anxiety & Between Groups & 62.12 & 3 & 20.70 & 1.14 & .33 \\
\hline
\end{tabular}

The way their employers treat them was significantly related to all three sub-scales. Those who were poorly treated reported higher levels of stress, anxiety, and depression (Table 10). 
Proceeding of the $2^{\text {nd }}$ Scientific Conference on Women's Health 2-3 September 2020 - Hawler Medical University

Table 10: ANOVA between the method of treatment and stress, anxiety, and depression

\begin{tabular}{|c|c|c|c|c|c|c|}
\hline & & $\begin{array}{l}\text { Sum of } \\
\text { Squares }\end{array}$ & df & Mean Square & $\mathrm{F}$ & Sig. \\
\hline \multirow[t]{3}{*}{ Stress } & Between Groups & 307.63 & 2 & 153.82 & 8.28 & .00 \\
\hline & Within Groups & 1652.68 & 89 & 18.56 & & \\
\hline & Total & 1960.32 & 91 & & & \\
\hline \multirow[t]{3}{*}{ Anxiety } & Between Groups & 218.19 & 2 & 109.09 & 6.65 & .00 \\
\hline & Within Groups & 1459.14 & 89 & 16.39 & & \\
\hline & Total & 1677.34 & 91 & & & \\
\hline \multirow[t]{3}{*}{ Depression } & Between Groups & 420.29 & 2 & 210.14 & 12.44 & .00 \\
\hline & Within Groups & 1503.40 & 89 & 16.89 & & \\
\hline & Total & 1923.70 & 91 & & & \\
\hline
\end{tabular}

The size of their employers' family was found to be significantly related to anxiety, but not stress or depression (Table 11). But the type of work they do in the house was not related to any of the sub-scales (Table 12).

Table 11: ANOVA between family size and stress, anxiety and depression

\begin{tabular}{|c|c|c|c|c|c|c|}
\hline & & $\begin{array}{l}\text { Sum of } \\
\text { Squares }\end{array}$ & $\mathrm{df}$ & Mean Square & $\mathrm{F}$ & Sig. \\
\hline \multirow[t]{3}{*}{ Stress } & Between Groups & 120.77 & 2 & 60.38 & 2.94 & .057 \\
\hline & Within Groups & 1863.32 & 91 & 20.47 & & \\
\hline & Total & 1984.09 & 93 & & & \\
\hline \multirow[t]{3}{*}{ Anxiety } & Between Groups & 153.13 & 2 & 76.56 & 4.52 & .013 \\
\hline & Within Groups & 1541.37 & 91 & 16.93 & & \\
\hline & Total & 1694.50 & 93 & & & \\
\hline \multirow[t]{3}{*}{ Depression } & Between Groups & 107.45 & 2 & 53.72 & 2.66 & .075 \\
\hline & Within Groups & 1835.85 & 91 & 20.17 & & \\
\hline & Total & 1943.31 & 93 & & & \\
\hline
\end{tabular}


Proceeding of the $2^{\text {nd }}$ Scientific Conference on Women's Health

2-3 September 2020 - Hawler Medical University

Table 12: ANOVA between the type of work and stress, anxiety and depression

\begin{tabular}{llccccc}
\hline & & $\begin{array}{c}\text { Sum of } \\
\text { Squares }\end{array}$ & df & Mean Square & F & Sig. \\
\hline Stress & Between Groups & 119.34 & 3 & 39.78 & 1.94 & .129 \\
& Within Groups & 1865.88 & 91 & 20.50 & & \\
Anxiety & Total & 1985.22 & 94 & & & \\
& Between Groups & 65.17 & 3 & 21.72 & 1.21 & .310 \\
& Within Groups & 1631.54 & 91 & 17.92 & & \\
& Total & 1696.71 & 94 & & & .057 \\
& Between Groups & 153.75 & 3 & 51.25 & 2.59 & \\
& Within Groups & 1797.69 & 91 & 19.75 & & \\
& Total & 1951.44 & 94 & & & \\
\hline
\end{tabular}

\section{DISCUSSION}

The study's main aim was to find out the level of mental health of Indonesian domestic female workers in the Kurdistan region/Iraq. The study found that the Mean general scores of the sample of stress, depression, and anxiety were normal. However, various percentages of the sample reported a mild and moderate stress, anxiety, and depression level. Compared to the study of Anjara in Singapore, ${ }^{4}$ less percentage of the sample in the current study reported stress. This might be due to different life conditions in both areas. The study in Macau by Valles found that 12 percent of Indonesian FDW suffered from depression, which is lower compared to the current study. ${ }^{6}$ Compared to Purba \& Abdul study in Malaysia, this study reported less severe depression. ${ }^{10}$

As far as demographic variables are concerned, the study found the more children that Indonesian FDW has, the higher their level of stress and depression. This is because of their feelings of longing for their children, despite frequent video calls, but having physical attachment is what they need more. The study has found that the less salary they received, the higher the level of stress and depression they get; since most of them are working more than 10 hours, they were supposed to receive more than this. Years of stay was positively correlated to depression only. The more they stay, the higher the level of depression; since most of them are married, the probability of missing their family is very high. Kurdish language proficiency was negatively correlated with stress and depression. The 


\section{Proceeding of the $2^{\text {nd }}$ Scientific Conference on Women's Health 2-3 September 2020 - Hawler Medical University}

better their Kurdish language proficiency, the less they feel stress and depress, Language is crucial in order the communication to run smoothly. The more the communication is smooth, the better mutual understanding they have and the less problem they face in their job. The way their employers treated them was significantly related to all sub-scales. Those who were treated badly reported higher levels of stress, anxiety, and depression. At the same time, the employer's family size was found to be significantly correlated to anxiety only. The larger the size of the family member, the more demands on the employee; thus, they become more anxious. Other demographic variables such as age, marital status, educational level, and types of works were not correlated to any of the sub-scales.

\section{CONCLUSIONS}

It is suggested that the next study to cover the whole Indonesian female domestic workers who are working in Iraq. New research on employers as well as domestic workers agency would be suggested to find out from their perspective about domestic workers attitude and behavior. Indonesian Embassy in Iraq is recommended to open an office in Kurdistan region to follow up the situation of female Indonesian workers in general, as their population is more in Kurdistan region, the researcher also suggested to have a kind on counseling services for those who are facing problems.

\section{REFERENCES}

1. Purba ,J,E., Abdullah,M,. The Effect of SFGBT On The Depression level Among Indonesian Women Migrant Workers in Malaysia. International Journal of Engineering \& Technology. 2018; 7 (3.21)529-535.

2. International Labour Organization (ILO) . New ILO Figures Show 164 Million People are Migrant Workers. ilo.org/global/about-the-ilo/newsroom/news/ WCMS_652106/lang-en/index.htm/retreived on 18/10/2019.

3. Muthia ,A. And Aliya, R,. Indonesian Migrant Domestic Workers Lack ProtectionHow Can Legal Academics Help?. THE CONVERSATION . Retrieved on 20th oct 2019.

4. Anjara, S,G., Nellums, L,B., Bonetto,C., Bortel,T,V,. Stress, Health and Quality of Life of Female Migrant Domestic Workers in Singapore : A Cross-Sectional Study, BMC Women's health, 2017; 17 (98): dot : 10.1186/s 12905-017-0442-7. 
Proceeding of the $2^{\text {nd }}$ Scientific Conference on Women's Health

2-3 September 2020 - Hawler Medical University

5. Lee, A,. Foreign Domestic Workers More Likely To Develop Mental Health Problems. 2019; TODAY.

6. Valles,L,. Migrant Workers: Studying Shows many Domestic Helpers Suffering from Depression. 2017; MACAU DAILY TIMES.

7. Kamber ,M,. Shame of Imported Labor in Kurdish North of Iraq, The New York Times 2007; dec, 29.

8. Romah,A,. Indonesia Bans its Maids from Working in Middle East, Anadolu Agency Website. 2015; www.AA.com.tr//en/world/indonesia-bans-its-maids-from- workingin-middle-east-5043.

9. Aria Chandra Utama . Personal Communication, Staff in Indonesian Embassy KBRI, Iraq. 2020.

10. Lovibond, S.H. \& Lovibond, P.F. Manual for the Depression Anxiety \& Stress Scale. 1995;( 2nd Ed). Sydney : Psychology Foundation. 